\title{
Induction Program for Trouble Shooting Basic Tools in Manufacturing Industries
}

\author{
S. Robin, G. Santhoshkumar, R. Velanganni
}

\begin{abstract}
To dismember the various advances related with the presentation getting ready program. To find the Satisfaction measurement of Employees towards the Induction program. To offer suggestions to improve the present Induction program.
\end{abstract}

Keywords :Induction,RM PVT LTD.

\section{INTRODUCTION}

Acknowledgment is a bit of socialization process which engages the newcomer to conform to their different affiliations and their social orders."

Which means and Concept of Induction: Induction is a contraption by which a worker is restored into the changed condition and tackles being shown, procedures and motivations driving the alliance. Constantly end, it is a fundamental advancement - tomake a newcomer feel at incredible in his very own extraordinary activity.The reason an acknowledgment blueprints to guarantee that all operators have the benefit of a truly sorted out Induction Program that will help them with coordinating into their activity in the affiliation quickly and effectively. Through the enrollment approach/plan process, delegates should have most of their fundamental starting presentation, prosperity, getting ready and information needs tended to.[1]-[4]

\section{RESEARCH METHODOLOGY}

Research approach is a way to deal with intentionally deal with the assessment issue. It may be appreciated as a science how investigate is deductively. The degree of research procedure is increasingly broad that of research system is progressively broad that of research techniques thusly, we talk about investigate reasoning. We not only dialog of the assessment himself or by others.

\section{RESEARCH DESIGN}

The assessment design is the historic procedure showing the techniques and frameworks for social event and dismembering the need information. The investigation arrangement is a blue print of action. It incorporates a movement of target fundamental administration choices regarding the explanation behind the assessment, its

Revised Manuscript Received on December 30, 2019.

S. Robin, Assistant professor, Department Of Science \& Humanities, Bharath Institute of Higher Education and Research ,Chennai, India.Email:srobin@gmail.com

G. Santhoshkumar, Assistant professor, Department Of Science \& Humanities, Bharath Institute of Higher Education and Research ,Chennai, India. .Email santhoshravi671026@gmail.com

R. Velanganni, Assistant professor, Department Of Science \& Humanities, Bharath Institute of Higher Education and Research ,Chennai, India. .Email velangannijose78516@gmail.com expansion, its zone, the kind of assessment, how much it is controlled and constrained by the master, the time points, the get-together, estimation and examination of data. It is a course of action and structure to find solution to the assessment questions

\section{ENGAGING RESEARCH}

Connecting with investigation has been used. This incorporates studies and reality disclosures enquirer of different sorts. The major purposed of realistic research is the delineation of the circumstance, as it exists at present. The essential characteristics of this system are that the researcher has no impact over the variable; he can simply report what happened or what's happening. The procedure for research use in clear research are audit methods for various kinds, including comparative and association systems.[5]-[8]

\section{RESULTS \& DUSCUSSION}

Primary Data and Secondary Data.

\section{A. Sampling technique}

he procedures used in representation tests from a people as a rule in such a manner, that the model will support confirmation of some hypothesis concerning the masses. The testing strategies are of two essential sorts which are according to the accompanying:

Probability Sampling

Findings

- In Chi-Square Analysis, it is induced that no essential association between capacity of the respondents and the satisfaction of delegate. In One Sample Run Test, it shows that the Samples are Random. [10]-[15]

- In Correlation Analysis, it shows that there is Positive Correlation between incredible impression and understand the movement of the laborers enrollment program.

Suggestion

- It is asked to finish the procedure of the joining customs before the direction developer.

- To spread the going with spaces in the determination program, a)Financial explanation of the past b) Strategic appealing system for the going with 5 years

- HR to control the newcomer on the most able procedure to research through the HR door.

- A delegate handbook with the going with substance is required to be given to the newcomers. an) Information as for affiliation b) Information on work openings c) Organizational charts d) Schedule of arranging programs. e) Information on qualifications and cutoff points f) Guidelines to utilize the path.[15]-[20]

- To make program more an intuitive session with seniors and to draw in the new joiner to illuminate 
request concerning their development.

\section{CONCLUSION}

To wrap up, the assessment rating of the direction software engineer by the workers is sensibly fantastic. In the event that the above said suggestion is considered, the enlistment developer will be continuously advantageous. It would in like way help in expanding the fulfillment level, soul and execution of the newcomers.[20]-[25]

\section{REFERENCES}

1. Vasanthi, S. \& Rabiyathul Basariya, S. 2019, "Influence of value analysis and cross training in industry", International Journal of Engineering and Advanced Technology, vol. 8, no. 6, pp. 1810-1811.

2. Velvizhi, R., Sri Gowtham, S. \& Jeya Priya, D. 2019, "Examination of early feedbacks for effective product retailing on E-commerce websites", International Journal of Engineering and Advanced Technology, vol. 8, no. 6 Special Issue 2, pp. 703-706.

3. Anuradha, C., Pothumani, S. \& Kavitha, R. 2019, "A novel method towards E-commerce", International Journal of Engineering and Advanced Technology, vol. 8, no. 6 Special Issue 2, pp. 535-538.

4. Thomas, J. \& Rabiyathul Basariya, S. 2019, "A study on the issues of financial ratio analysis", Indian Journal of Public Health Research and Development, vol. 10, no. 3, pp. 1079-1081.

5. Ramachandran, S. \& Rabiyathul Basariya, S. 2019, "Online marketing - study on customer satisfaction and relationship", Indian Journal of Public Health Research and Development, vol. 10, no. 3, pp. 1072-1078.

6. Priya, R., Vinothini, G. \& Cor Jesu, C.D. 2019, "The mentor-protégé relationship for professional growth", Journal of Advanced Research in Dynamical and Control Systems, vol. 11, no. 9 Special Issue, pp. 1110-1119.

7. Jannifer Rani, N., Bina Pani, S. \& Nimisha, N.S. 2019, "A study on money back polices available in LIC", Journal of Advanced Research in Dynamical and Control Systems, vol. 11, no. 9 Special Issue, pp. 833-839.

8. Saillaja, V., Jhansi Rani, K. \& Catherine, R. 2019, "Global marketing management planning and organization", Journal of Advanced Research in Dynamical and Control Systems, vol. 11, no. 9 Special Issue, pp. 489-493.

9. Saillaja, V., Jhansi Rani, K. \& Catherine, R. 2019, "The new phase of marketing information system", Journal of Advanced Research in Dynamical and Control Systems, vol. 11, no. 9 Special Issue, pp. 482-488.

10. Thoufiqulla \& Raju, D.V. 2019, "Perception of indian investor towards investment in mutual funds with special reference to mip funds", Journal of Advanced Research in Dynamical and Control Systems, vol. 11, no. 5, pp. 177-183.

11. Jasmine, K.R.M. \& Basariya, S.R. 2018, "A study on the customers benefits on mutual funds", International Journal of Civil Engineering and Technology, vol. 9, no. 4, pp. 45-48.

12. Vasanthi, S. \& Basariya, S.R. 2019, "Pros and cons of on the job training versus off the job training", International Journal of Scientific and Technology Research, vol. 8, no. 10, pp. 671-674.

13. Pavithra, J. \& Ganesan, M. 2016, "A study on awareness and impact of micro-financial schemes", International Journal of Applied Business and Economic Research, vol. 14, no. 8, pp. 5449-5460.

14. Pavithra, J., Dilli Babu, P. \& Ambuli, T.V. 2014, "A study on budgetary control at Maruti Service Masters, Chennai", International Journal of Applied Business and Economic Research, vol. 12, no. 2 , pp. 151-161.

15. Gunaraja, T.M. \& Venkatrama Raju, D. 2018, "Determining factors of organisational climate with reference to leadership styles", International Journal of Mechanical Engineering and Technology, vol. 9, no. 9, pp. 1327-1332.

16. Gunaraja, T.M. \& Venkatrama Raju, D. 2018, "The role of job satisfaction and training of employees in determining organisational climate of a selected industry", International Journal of Civil Engineering and Technology, vol. 9, no. 8, pp. 1266-1269.

17. Aarathy, T.S. \& Raju, D.V. 2018, "Performance appraisal and its effects on employees with respect to it sector in Chennai city", International Journal of Civil Engineering and Technology, vol. 9, no. 6, pp. 1535-1538.
18. Aarathy, T.S. \& Raju, D.V. 2018, "Employee perception towards performance appraisal system in IT sector", International Journal of Mechanical Engineering and Technology, vol. 9, no. 5, pp. 131-135.

19. Porselvi, W., Jublee, D. \& Sivanesan, G. 2018, "A study on factors influencing adoption of technology and innovation in banking industry, tamilnadu, India", International Journal of Mechanical Engineering and Technology, vol. 9, no. 5, pp. 789-800.

20. Akessa, G.M. and Dhufera, A.G., 2015. Factors That Influences Students Academic Performance: A Case of Rift Valley University, Jimma, Ethiopia. Journal of Education and Practice, 6(22), pp.55-63.

21. Miller, G. and Shih, C.C., 1999. A faculty assessment of the academic rigor of on-and off-campus courses in agriculture. Journal of Agricultural Education, 40, pp.57-65.

22. Tsinidou, M., Gerogiannis, V. and Fitsilis, P., 2010. Evaluation of the factors that determine quality in higher education: an empirical study. Quality Assurance in education, 18(3), pp.227-244.

23. Farooq, M.S., Chaudhry, A.H., Shafiq, M. and Berhanu, G., 2011. Factors affecting students' quality of academic performance: a case of secondary school level. Journal of quality and technology management, 7(2), pp.1-14.

24. Fitsilis, P., Gerogiannis, V. and Anthopoulos, L., 2014. Ontologies for software project management: a review. Journal of Software Engineering and Applications, 7(13), p.1096.

25. Adams, J.D. and Jaffe, A.B., 1996. Bounding the effects of R\&D: an investigation using matched establishment-firm data(No. w5544). National bureau of economic research.

\section{AUTHORS PROFILE}

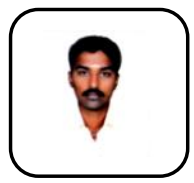

S. Robin, Assistant professor, Department Of Science \& Humanities, Bharath Institute of Higher Education and Research ,Chennai, India

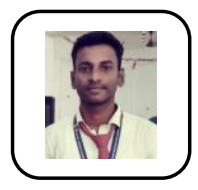

G. Santhoshkumar, Assistant professor, Department Of Science \& Humanities, Bharath Institute of Higher Education and Research ,Chennai, India. .

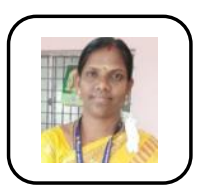

R. Velanganni, Assistant professor, Department Of Science \& Humanities, Bharath Institute of Higher Education and Research ,Chennai, India. 